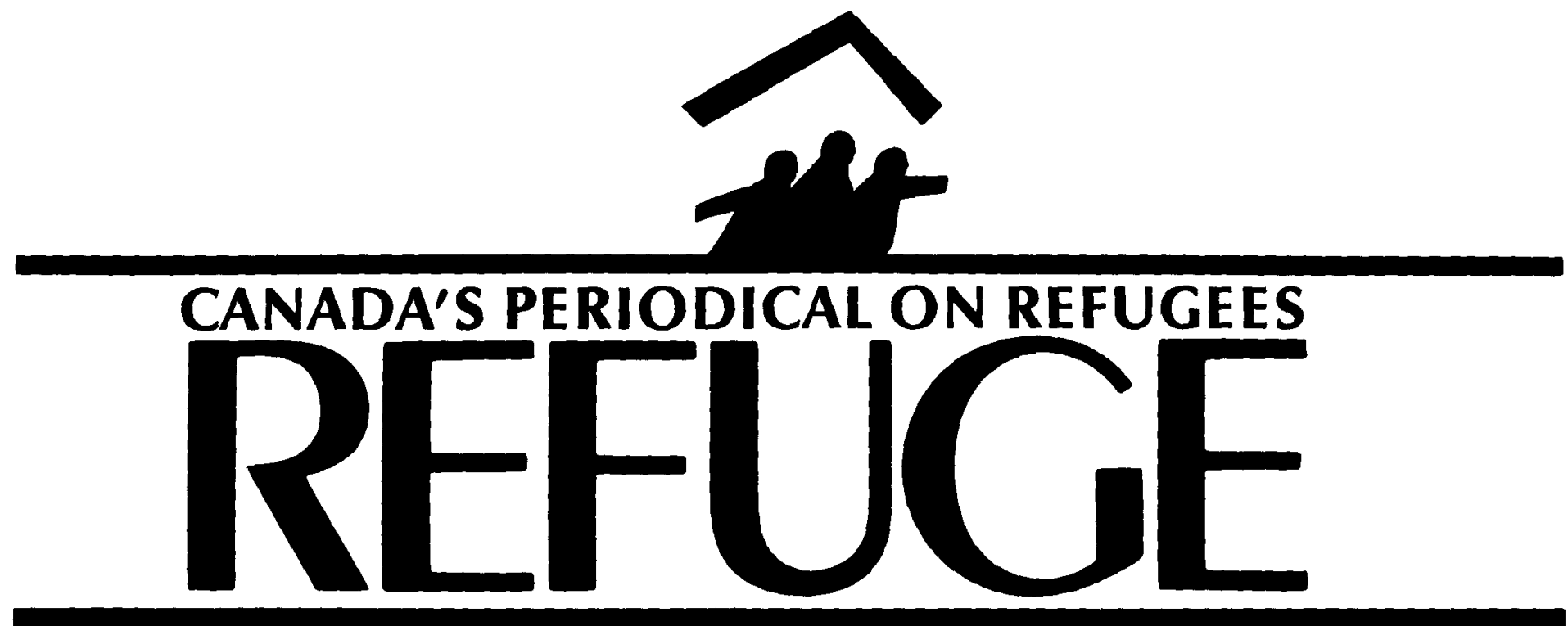

Vol. 6 , No. 1

October 1986

\title{
A Time to Rejoice
}

"The United Nations High Commissioner for Refugees, Mr. Jean-Pierre Hocké, announced today that the Nansen Medal Committee has decided to award the $1986 \mathrm{Medal}$ to the People of Canada in recognition of the major and sustained contribution made to the cause of refugees in their country and throughout the world over the years." (Press release. United Nations, October 6, 1986)

Very rarely do Canadians working with and for refugees have occasion to rejoice -- there are ten million reasons not to.

The news of October 6th brought us up short. Impersonal and distant non-governmental organizations have been watching Canadians in their official and even everyday humanitarian work. Every Canadian has the sovereign right to be proud of this singular honour, awarded for the first time to all the people of a country. The Canadian effort on behalf of refugees has been collective. It has been animated in local community groups, in agencies and in provincial and federal government ministries in Canada and abroad. It has extended from resettlement in Canada through sustained and sometimes bold efforts to provide Canada's protection nearer their homeland.

November 13th will be the day for momentary rejoicing, to take satisfaction in our efforts, however fledgling and chequered with partial results and half-successes these may be.

But all goods things come to an end -- so too with the new-found Canadian euphoria. We can do no greater service in the spirit of Hansen than to be critical of the refugee situation everywhere -- no less in Canada than in countries where social conditions force involuntary migration. And to be critical no less of our own work than of our government's policy.
Thus Refuge highlights here two major themes which bring us quickly back to order: first, the issue of refugee determination policy and secondly, that of receiving refugees with wellfounded fears of persecution who arrive in a manner to which Canada is unaccustomed.

In these pages Tom Clark underscores the unflagging insistence of the Inter-Church Committee for Refugees on principles of due process for all claimants arriving at Canada's borders. Rabbi W. Gunther Plaut cogently reminds us of the sensibility of these propositions for Canadian life: to treat refugees otherwise is to practice the very discrimination which Canada could eradicate.

The Canadian government's position, too, appears plausible. Due process will be assured but within limits which the government considers practical, and cost-efficient. And government representatives are unwilling to forward policy which in its estimation, it cannot responsibly deliver. Refugee policy is one among many games in the political arena. It is subject to the same type of compromises as foreign aid and wheat subsidies.
The gap remains, bridged by political leaders begging for time and patience, reminding the advocate that yet another round of bargaining will occur in next year's promised consultation.

Yet refugee affairs are affairs of the moment Certainly the recent arrival of Tamils in Canada illustrates that point. The Tamils unanimously claim past and potential future persecution in Sri Lanka. There appeared no other means of affording them protection collectively as well as individually than to grant them temporary asylum and rights to seek employment and to enjoy health and social assistance benefits while awaiting hearings for judgement on their cases. By all accounts, Canada's move appears at once generous and sensible.

But it is not undebatable. If these Tamil claimants arrived from West Germany, which also granted them asylum, why did they not remain there? How does this particular group differ from other refugees who are discontented with their country of refuge and wish to rejoin family members here? Is ingenuity rather than need for asylum being reinforced in this instance?

Continued on p. 2

\section{IN THIS ISSUE:}

Refugee Determination in Canada by Raphael Girard

Principles and Questions by W. Gunther Plaut

page 3

The Government's Refugee Determination

Forum

Proposals: An Update by Tom Clark

page 4

An Interview on the Case of the 155 Tamil

Refugees with Sri Guggan Sri-Skanda-Rajah

page 5

page 7

page 8 
A Time to Rejoice (continued from $p .1$ )

The respective responsibilities of two governments are also spotlighted. How often and under what circumstances will Canada be asked to "share the burden" of accepting asylumseekers from countries where asylum has already been granted? Should Canada routinely receive claimants from countries like West Germany, which discourages refugee arrivals by detention and deprivation of other civil rights, but which at present protects them from refoulement and other perils?
These questions will not pass with the successful adaptation of the small number of refugee claimants from Sri Lanka. Very soon the Canadian government will have to argue that such acts of compassion also have limits -- not only on the number of refugee claimants, but also on the conditions under which third countries such as West Germany may send their claimants to Canada.

Advocates insist that more is better and that quotas are irrelevant in the humanitarian cause of assitance to refugees. By selectively reinforcing actions of the government such as granting asylum to the Tamil claimants, the urgent points are effectively pressed.

Government for its part will have to enunciate clearly its practical operation. When can we Canadians expect the generous response? How flexible will its policy be without bringing confusion to the very realm which has recognized Canada as its most distinguished contributor? With the gleam of honour comes the rub of increased responsibility. A time to rejoice is a time for sober reflection.

C. Michael Lanphier

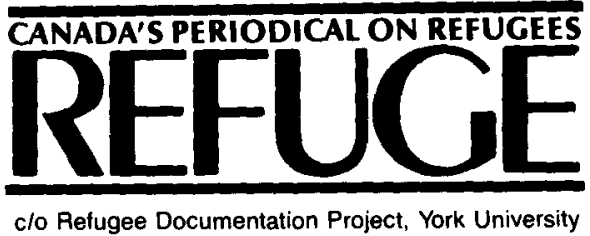

c/o Refugee Documentation Project, York University
4700 Keele Street, North York, Ontario M3J 1P3

Editor:

C. Michael Lanphier

Feature Editor:

Alex Zisman

Managing Editor:

Noreen Nimmons

Editorial Assistant:

Alice Dinerman

Refuge is dedicated to encouraging assistance to refugees, by providing a forum for sharing information and opinion on Canadian and international issues pertaining to refugees. It is published four times a year by the Refugee Documentation Project. It is a non-profit, independent periodical supported by private donations and by subscriptions. It is a forum for discussion, and the views expressed do not necessarily reflect those of its funders or staff.

All material in Refuge may be reproduced without permission unless copvrighted or otherwise indicated. Credit should be given to the author or source if named.

Subscription rates for one year are $\$ 20.00$. Please enclose payment with your orde'r No discounts can be given for American funds because of hank charges for foreign cheques

Logo design:

Dreadnaught Cooperative Inc., Toronto

Second Class Mail Registration No. 5512 ISSN 0229-5113

\section{The Nansen Medal}

The Nansen Medal is named in honour of Dr. Fridtjof Nansen (1861-1930), an eminent Norwegian scientist and humanist whose diverse activities ranged from exploration of Northern regions through intricate diplomacy.

His contributions to the international assistance to refugees, notably co-ordinating rapid repatriation of some 450,000 prisoners of war after World War I, culminated in his appointment in 1921 to first High Commissioner for Refugees for the League of Nations. He organized the League's refugee efforts to bring about self-sufficiency among refugees.

The Nansen passport for (stateless) refugees was adopted in 1922. Subsequent refugee laws, including financing activities on behalf of refugees under his direction, reflect his pioneering efforts.
The Nansen Medal, struck in 1954, was first awarded to Eleanor Roosevelt and her late husband (President Franklin D. Roosevelt) for initiative in establishing the Inter-governmental Committee on Refugees.

Subsequent recipients have included heads of state, prominent figures in assistance to refugees, as well as individuals who have performed heroically for refugees.

The Nansen Committee, headed by the High Commissioner and composed of nominees of the Norwegian and Swiss governments, and the chair of the commission on refugees of the International Council of Voluntary Agencies, is free to nominate any person or organization. This year the Committee has accorded the medal to a nation, the People of Canada, for the first time. 